\title{
Effectiveness of atmospheric cold plasma technology on physicochemical and functional characteristics of ST25 fragrant rice (Oryza sativa L.) flour
}

\author{
Nguyen Phuoc Minh \\ Institute of Applied Technology, Thu Dau Mot University, Binh Duong Province, Vietnam \\ *Email: nguyenphuocminh@tdmu.edu.vn
}

\section{ARTICLE HISTORY}

Received: 03 June 2021

Accepted: 27 June 2021

Available online: 07 July 2021

\section{KEYWORDS}

Functional characteristics

Physicochemical characteristics

Plasma technology

Oxygen flow rate

Fragrant rice

\section{ABSTRACT}

Vietnam is one of the leading rice export countries in the world. ST25 fragrant rice (Oryza sativa L.) won the top prize for best rice in the world in 2019 and the second at World's Best Rice Contest 2020. Plasma has been considered as an innovative food processing technology. The aim of this study demonstrated the impact of time (4, 6, 8, 10, $12 \mathrm{~min})$, power (160, 180, 200, 220, $240 \mathrm{~W}$ ) and oxygen flow rate $(0.2,0.4,0.6,0.8,1.0 \mathrm{ml} / \mathrm{min})$ to the physicochemical and functional qualities of ST25 fragrant rice flour. Results showed that under plasma treatment time at 10 minutes, power $200 \mathrm{~W}$, oxygen flow rate $0.8 \mathrm{ml} / \mathrm{min}$, the amylose content $(16.67 \pm 0.01 \%)$, pasting temperature $\left(83.21 \pm 0.02{ }^{\circ} \mathrm{C}\right)$, water absorption index (14.54 $\pm 0.00 \mathrm{gm} / \mathrm{gm}$ sample), water solubility index $(10.31 \pm 0.02 \mathrm{gm} / 100 \mathrm{gm}$ sample), swelling power ( $14.96 \pm 0.00 \mathrm{gm} / \mathrm{gm}$ sample) were recorded. Under plasma treatment, surface of the ST25 fragrant rice flour became more hydrophilic to absorb more water resulting to shorter cooking time. Plasma treatment provides environmentally friendly processing of rice grain to limit pesticide abuse towards ecological farming.

\section{Introduction}

Rice (Oryza sativa L.) is one of the most important grown cereals and is the leading crops as the main ingredient of human nutrition $(1,2)$. It contains a great source of carbohydrates, proteins, vitamins and minerals (3). ST25 fragrant rice is indexed in the highquality rice list with excellent economic value in export (4). ST25 fragrant rice is not only appreciated in nutritional quality but also highly valued in overall acceptability. It well resists to disease and highly adapt to the cultivation farm. This rice variety can be cultivated twice crops per year with higher yield than other rice varieties on the same area. In 2019, it's ranked the top prize and in 2020, the second for best rice in the world in World's Best Rice Contest.

Plasma has been discovered as an innovative approach in food processing industry. Plasma is mainly consisted of photons, ions, free electrons and atoms generated from corona discharge or dielectric barrier discharge $(5,7)$. Two types of plasma include thermal plasma and non-thermal plasma (8). The most advantages of plasma technology are safe, flexible, cheap (9). Moreover, it also releases reactive components as oxidative reagent without toxic residue (10). Plasma technology has been reported to be effective seed germination, microbial-insect-pest inactivation, enzyme inactivation and shelf-life extension of green vegetable $(11,12)$; surface disinfection, seed germination, vitality improving, decontamination, flour modification and pesticide mitigation on cereal grain $(9,13,14)$. Plasma technology remarkably affects water permeability of grain without any damage outside (7). There were several literature mentioned to the application of plasma treatment on rice. Brown rice treated by direct current gaseous discharge plasma resulted to more water uptake (15). Plasma treatment caused a decrease in cooking duration and improvement in water uptake ratio, length expansion ratio and volume expansion ratio, water absorption of pigmented Thai rice (8). Cold plasma treatment was utilized to enhance cooking quality of basmati rice (16). Plasma treatment reduced the cooking time with soft texture firmness of parboiled rice $(17,19)$. Nonthermal plasma improved water absorption and reduce the cooking time in bamboo rice (20). Low pressure cold plasma greatly affected cooking and textural attributes of brown rice (21). Plasma treatment at $120 \mathrm{~W}$ for $20 \mathrm{~s}$ strongly reduced the cooking duration and the firmness of cooked rice while accelerating stickiness, elasticity, and gruel solid loss in Chinese milled rice (22). The main objective of our study was to verify the impact of different parameters of plasma treatments

(c) Minh (2021). This is an open-access article distributed under the terms of the Creative Commons Attribution License, which permits unrestricted use, distribution and reproduction in any medium, provided the original author and source are credited (https://creativecommons.org/licenses/by/4.0/). 
such as time, power and oxygen flow rate to the physicochemical and functional qualities of ST25 fragrant rice flour.

\section{Materials and Methods}

\section{Material}

ST25 fragrant rice paddy was cultivated in Soc Trang province, Vietnam. After harvesting on the field, paddy rice was passed through following steps to obtain rice grain: drying to $14 \%$ moisture content, temporary storage for 2 weeks, cleaning, hulling, milling, polishing, grading, sorting and packaging. Rice grain was finely ground by grinder to obtain rice flour. Chemical reagents such as sodium hydroxide, acetic acid, ethanol, iodine were all analytical grade (> $95 \%$ in purity) purchased from Rainbow Trading Co. Ltd., Vietnam. Lab equipments and utensils included weight balance, centrifugator, UV-Vis spectrophotometer, viscometer, infrared drying oven, vortex mixer and test tube.

\section{Experiments}

\section{Experiment \#1}

Effect of treatment time (min) to physicochemical and functional properties of ST25 fragrant rice flour. The ST25 fragrant rice flour was subjected to plasma treatment under different durations $(4,6,8,10,12$ $\mathrm{min}$ ) at power $160 \mathrm{~W}$ and oxygen flow rate 0.2 $\mathrm{ml} / \mathrm{min}$.

\section{Experiment \#2}

Effect of treatment power (W) to physicochemical and functional properties of ST25 fragrant rice flour. The ST25 fragrant rice flour was subjected to plasma treatment in $10 \mathrm{~min}$ under different power values $(160,180,200,220,240 \mathrm{~W})$ at oxygen flow rate $0.2 \mathrm{ml} /$ $\min$.

\section{Experiment \#3}

Effect of treatment oxygen flow rate (L/min) to physicochemical and functional properties of ST25 fragrant rice flour. The ST25 fragrant rice flour was subjected to plasma treatment in $10 \mathrm{~min}$ under power $200 \mathrm{~W}$ at different oxygen flow rates $(0.2,0.4$, 0.6, 0.8, $1.0 \mathrm{ml} / \mathrm{min})$.

The target functions in each experiment were based on amylose content (\%), water absorption index (gm/gm sample), water solubility index (gm/100 gm sample), swelling power (gm/gm sample), pasting temperature $\left({ }^{\circ} \mathrm{C}\right)$.

\section{Physicochemical Evaluation}

Amylose content (\%) was determined by Iodinebinding procedure (23). $0.5 \mathrm{gm}$ of rice flour was blended with $5 \mathrm{ml}$ of $90 \%$ ethanol and $95 \mathrm{ml}$ of $1 \mathrm{~N}$ $\mathrm{NaOH}$, keeping at ambient condition for $15 \mathrm{~min}$. This blend was boiled for $5 \mathrm{~min}$ then cooled to $30{ }^{\circ} \mathrm{C}$. Aliquot of $500 \mathrm{ml}$ of distilled water was added and mixed thoroughly. This blend was supplemented with $50 \mathrm{ml}$ of acetic acid and $1 \mathrm{ml}$ of iodine. The absorbance was read at $620 \mathrm{~nm}$ of UV-Vis spectrophotometer.
Water absorption index or WAI (gm/gm sample) was estimated as following procedure (24). $1 \mathrm{gm}\left(\mathrm{M}_{1}\right)$ of rice flour was mixed with $10 \mathrm{ml}$ of distilled water. Mixture was boiled for $5 \mathrm{~min}$ then cooled to $30{ }^{\circ} \mathrm{C}$. Supernatant of the boiled mixture was decanted by centrifugator, and then heated at $105{ }^{\circ} \mathrm{C}$ to constant weight $\left(\mathrm{M}_{2}\right)$. Flour residue $\left(\mathrm{M}_{\mathrm{r}}\right)$ was balanced (gm).

WAI (gm/gm sample) $=\mathrm{M}_{\mathrm{r}} / \mathrm{M}_{1}$

Swelling power or SP (gm/gm sample) $=M_{r} /\left(M_{1}-M_{2}\right)$

Water solubility index or WSI (gm/100 gm sample) $=100 * \mathrm{M}_{2} / \mathrm{M}_{1}$

Pasting temperature $\left({ }^{0} \mathrm{C}\right)$ was examined by viscometer (25). $5 \mathrm{gm}$ of rice flour was mixed with 95 $\mathrm{ml}$ of distilled water. This mixture was boiled to $90{ }^{\circ} \mathrm{C}$, kept $4 \mathrm{~min}$ and cooled to $45^{\circ} \mathrm{C}$. Pasting temperature was derived from the pasting curve.

\section{Statistical Summary}

The demonstrations were prepared as 3 replicates for various sample groups. The values were expressed as mean \pm standard deviation. Statistical summary was done using Statgraphics version XVI.

\section{Results and Discussion}

\section{Effect of Treatment Time to Physicochemical and Functional Properties of ST25 Fragrant Rice Flour}

Impact of treatment time of plasma technology to physicochemical and functional properties of ST25 fragrant rice flour was shown in Table 1. When increasing treatment time (4-12 $\mathrm{min})$, amylose content slightly degraded $(18.95 \pm 0.01$ to $17.75 \pm 0.03$ $\%)$, pasting temperature also went down $(86.05 \pm 0.02$ to $84.90 \pm 0.02{ }^{\circ} \mathrm{C}$ ); meanwhile, water absorption index, water solubility index, swelling power were significantly increased $(12.24 \pm 0.00$ to $13.04 \pm 0.02 \mathrm{gm} /$ gm sample, $8.70 \pm 0.02$ to $8.96 \pm 0.01 \mathrm{gm} / 100 \mathrm{gm}$ sample, $12.55 \pm 0.00$ to $13.39 \pm 0.00 \mathrm{gm} / \mathrm{gm}$ sample respectively). There was not significant difference between treatment time $10 \mathrm{~min}$ and $12 \mathrm{~min}$, the amylose content $(17.89 \pm 0.02 \%)$, pasting temperature $\left(84.92 \pm 0.03{ }^{\circ} \mathrm{C}\right)$, water absorption index $(13.02 \pm 0.01$ $\mathrm{gm} / \mathrm{gm}$ sample), water solubility index $(8.95 \pm 0.00 \mathrm{gm} /$ $100 \mathrm{gm}$ sample), swelling power $(13.35 \pm 0.02 \mathrm{gm} / \mathrm{gm}$ sample) were recorded at treatment time $10 \mathrm{~min}$.

\section{Effect of Treatment Power to Physicochemical and Functional Properties of ST25 Fragrant Rice Flour}

Impact of treatment power of plasma technology to physicochemical and functional properties of ST25 fragrant rice flour was was expressed in Table 2. When increasing treatment power (160-240 W), amylose content slightly degraded $(17.89 \pm 0.02$ to $16.79 \pm 0.02 \%$ ), pasting temperature also went down $\left(84.92 \pm 0.03\right.$ to $\left.83.38 \pm 0.01{ }^{\circ} \mathrm{C}\right)$; meanwhile, water absorption index, water solubility index, swelling power were significantly increased $(13.02 \pm 0.01$ to $13.73 \pm 0.00 \mathrm{gm} / \mathrm{gm}$ sample, $8.95 \pm 0.00$ to $9.52 \pm 0.03$ $\mathrm{gm} / 100 \mathrm{gm}$ sample, $13.35 \pm 0.02$ to $13.99 \pm 0.01 \mathrm{gm} / \mathrm{gm}$ sample respectively). By treatment power $200 \mathrm{~W}$, the amylose content (17.05 $\pm 0.02 \%)$, pasting temperature $\left(84.01 \pm 0.01{ }^{\circ} \mathrm{C}\right)$, water absorption index $(13.65 \pm 0.01$ 
gm/gm sample), water solubility index $(9.46 \pm 0.00 \mathrm{gm} /$ $100 \mathrm{gm}$ sample) and swelling power (13.95 $\pm 0.02 \mathrm{gm} /$ gm sample) were recorded.

\section{Impact of Treatment Oxygen Flow Rate to Physicochemical and Functional Properties of ST25 Fragrant Rice Flour}

Effect of treatment oxygen flow rate (L/min) to physicochemical and functional properties of ST25 recorded at treatment oxygen flow rate $0.8 \mathrm{ml} / \mathrm{min}$. Plasma has been considered as a beneficial nonthermal emerging technique for rice grain treatment by its capability to inactivate enzyme; disinfect microbial, pest and insect without creating thermal injury and free from toxic residue (26). Plasma technology significantly improved the functional properties of wheat grain and wheat flour (7). Brown rice treated by direct current gaseous discharge

Table 1. Effect of treatment time (min) to physicochemical and functional properties of ST25 fragrant rice flour

\begin{tabular}{|c|c|c|c|c|c|}
\hline Treatment time (min) & 4 & 6 & 8 & 10 & 12 \\
\hline $\begin{array}{l}\text { Amylose content } \\
(\%)\end{array}$ & $18.95 \pm 0.01^{\mathrm{a}}$ & $18.66 \pm 0.03^{\mathrm{ab}}$ & $18.13 \pm 0.01^{\mathrm{ab}}$ & $17.89 \pm 0.02^{b}$ & $17.75 \pm 0.03^{b}$ \\
\hline $\begin{array}{l}\text { Water absorption index } \\
\text { (gm/gm sample) }\end{array}$ & $12.24 \pm 0.00^{\mathrm{b}}$ & $12.53 \pm 0.01^{\mathrm{ab}}$ & $12.81 \pm 0.00^{\mathrm{ab}}$ & $13.02 \pm 0.01^{\mathrm{a}}$ & $13.04 \pm 0.02^{\mathrm{a}}$ \\
\hline $\begin{array}{l}\text { Water solubility index } \\
\text { (gm/100 gm sample) }\end{array}$ & $8.70 \pm 0.02^{b}$ & $8.79 \pm 0.03^{\mathrm{ab}}$ & $8.87 \pm 0.02^{\mathrm{ab}}$ & $8.95 \pm 0.00^{\mathrm{a}}$ & $8.96 \pm 0.01^{\mathrm{a}}$ \\
\hline $\begin{array}{l}\text { Swelling power } \\
\text { (gm/gm sample) }\end{array}$ & $12.55 \pm 0.00^{\mathrm{b}}$ & $12.81 \pm 0.02^{\mathrm{ab}}$ & $13.07 \pm 0.03^{\mathrm{ab}}$ & $13.35 \pm 0.02^{\mathrm{a}}$ & $13.39 \pm 0.00^{\mathrm{a}}$ \\
\hline $\begin{array}{l}\text { Pasting temperature } \\
(\cdot \mathrm{C})\end{array}$ & $86.05 \pm 0.02^{\mathrm{a}}$ & $85.89 \pm 0.01^{\mathrm{ab}}$ & $85.37 \pm 0.00^{\mathrm{ab}}$ & $84.92 \pm 0.03^{b}$ & $84.90 \pm 0.02^{b}$ \\
\hline
\end{tabular}

Figures are the mean of three replications; Figures in row followed by the same letter/s are not differed significantly ( $\alpha=\mathrm{P}=0.05$ ).

Table 2. Effect of treatment power (W) to physicochemical and functional properties of ST25 fragrant rice flour

\begin{tabular}{|c|c|c|c|c|c|}
\hline Treatment power (W) & 160 & 180 & 200 & 220 & 240 \\
\hline $\begin{array}{l}\text { Amylose content } \\
(\%)\end{array}$ & $17.89 \pm 0.02^{\mathrm{a}}$ & $17.26 \pm 0.01^{\mathrm{ab}}$ & $17.05 \pm 0.02^{\mathrm{ab}}$ & $16.83 \pm 0.03^{\mathrm{b}}$ & $16.79 \pm 0.02^{b}$ \\
\hline $\begin{array}{l}\text { Water absorption index } \\
\text { (gm/gm sample) }\end{array}$ & $13.02 \pm 0.01^{b}$ & $13.26 \pm 0.03^{\mathrm{ab}}$ & $13.65 \pm 0.01^{\mathrm{a}}$ & $13.70 \pm 0.02^{\mathrm{a}}$ & $13.73 \pm 0.00^{\mathrm{a}}$ \\
\hline $\begin{array}{l}\text { Water solubility index } \\
\text { (gm/100 gm sample) }\end{array}$ & $8.95 \pm 0.00^{\mathrm{b}}$ & $9.22 \pm 0.02^{\mathrm{ab}}$ & $9.46 \pm 0.00^{\mathrm{a}}$ & $9.49 \pm 0.01^{\mathrm{a}}$ & $9.52 \pm 0.03^{\mathrm{a}}$ \\
\hline $\begin{array}{l}\text { Swelling power } \\
\text { (gm/gm sample) }\end{array}$ & $13.35 \pm 0.02^{\mathrm{b}}$ & $13.64 \pm 0.01^{\mathrm{ab}}$ & $13.95 \pm 0.02^{\mathrm{a}}$ & $13.98 \pm 0.03^{\mathrm{a}}$ & $13.99 \pm 0.01^{\mathrm{a}}$ \\
\hline $\begin{array}{l}\text { Pasting temperature } \\
(\circ \mathrm{C})\end{array}$ & $84.92 \pm 0.03^{\mathrm{a}}$ & $84.37 \pm 0.00^{\mathrm{ab}}$ & $84.01 \pm 0.01^{\mathrm{b}}$ & $83.69 \pm 0.00^{\mathrm{bc}}$ & $83.38 \pm 0.01^{\mathrm{c}}$ \\
\hline
\end{tabular}

Figures are the mean of three replications; Figures in row followed by the same letter/s are not differed significantly $(\alpha=P=0.05)$.

Table 3. Effect of treatment oxygen flow rate (L/min) to physicochemical and functional properties of ST25 fragrant rice flour

\begin{tabular}{|c|c|c|c|c|c|}
\hline $\begin{array}{l}\text { Oxygen flow rate } \\
\text { (L/min) }\end{array}$ & 0.2 & 0.4 & 0.6 & 0.8 & 1.0 \\
\hline $\begin{array}{l}\text { Amylose content } \\
(\%)\end{array}$ & $17.05 \pm 0.02^{\mathrm{a}}$ & $17.01 \pm 0.03^{\mathrm{a}}$ & $16.85 \pm 0.00^{\mathrm{ab}}$ & $16.67 \pm 0.01^{b}$ & $16.62 \pm 0.03^{b}$ \\
\hline $\begin{array}{l}\text { Water absorption index } \\
\text { (gm/gm sample) }\end{array}$ & $13.65 \pm 0.01^{b}$ & $13.72 \pm 0.00^{\mathrm{b}}$ & $14.05 \pm 0.02^{\mathrm{ab}}$ & $14.54 \pm 0.00^{\mathrm{a}}$ & $14.60 \pm 0.01^{\mathrm{a}}$ \\
\hline $\begin{array}{l}\text { Water solubility index } \\
\text { (gm/100 gm sample) }\end{array}$ & $9.46 \pm 0.00^{\mathrm{b}}$ & $9.51 \pm 0.01^{b}$ & $9.92 \pm 0.03^{\mathrm{ab}}$ & $10.31 \pm 0.02^{\mathrm{a}}$ & $10.36 \pm 0.00^{\mathrm{a}}$ \\
\hline $\begin{array}{l}\text { Swelling power } \\
\text { (gm/gm sample) }\end{array}$ & $13.95 \pm 0.02^{\mathrm{b}}$ & $13.99 \pm 0.03^{b}$ & $14.41 \pm 0.01^{\mathrm{ab}}$ & $14.96 \pm 0.00^{\mathrm{a}}$ & $15.00 \pm 0.02^{\mathrm{a}}$ \\
\hline $\begin{array}{l}\text { Pasting temperature } \\
(\circ \mathrm{C})\end{array}$ & $84.01 \pm 0.01^{\mathrm{a}}$ & $83.99 \pm 0.02^{\mathrm{a}}$ & $83.65 \pm 0.03^{\mathrm{ab}}$ & $83.21 \pm 0.02^{\mathrm{b}}$ & $83.18 \pm 0.03^{b}$ \\
\hline
\end{tabular}

Figures are the mean of three replications; Figures in row followed by the same letter/s are not differed significantly ( $\alpha=\mathrm{P}=0.05)$.

fragrant rice flour was expressed in Table 3. When increasing treatment oxygen flow rate $(0.2-1.0 \mathrm{l} / \mathrm{min})$, amylose content slightly degraded $(17.05 \pm 0.02$ to $16.62 \pm 0.03 \%$ ), pasting temperature also went down $\left(84.01 \pm 0.01\right.$ to $\left.83.18 \pm 0.03{ }^{\circ} \mathrm{C}\right)$; meanwhile, water absorption index, water solubility index, swelling power were significantly increased $(13.65 \pm 0.01$ to $14.60 \pm 0.01 \mathrm{gm} / \mathrm{gm}$ sample, $9.46 \pm 0.00$ to $10.36 \pm 0.00 \mathrm{gm} /$ $100 \mathrm{gm}$ sample, $13.95 \pm 0.02$ to $15.00 \pm 0.02 \mathrm{gm} / \mathrm{gm}$ sample respectively). There was not significant difference between treatment oxygen flow rate 0.8 $\mathrm{ml} / \mathrm{min}$ and $1.0 \mathrm{ml} / \mathrm{min}$, the amylose content $(16.67 \pm 0.01 \%)$, pasting temperature $\left(83.21 \pm 0.02{ }^{\circ} \mathrm{C}\right)$, water absorption index (14.54 $\pm 0.00 \mathrm{gm} / \mathrm{gm}$ sample), water solubility index (10.31 $\pm 0.02 \mathrm{gm} / 100 \mathrm{gm}$ sample), swelling power $(14.96 \pm 0.00 \mathrm{gm} / \mathrm{gm}$ sample) were plasma at power $1-3 \mathrm{kV}$, pressure $800 \mathrm{~Pa}$ by air in 10 min induced to more water uptake (15). Plasma treatment induced short cooking time and soft texture firmness of parboiled rice (17-19). Nonthermal plasma improved water absorption and reduce the cooking time by $12 \mathrm{~min}$ in bamboo rice. Final viscosity of the plasma-treated flour lowered to $306 \mathrm{cP}$ (20). The water uptake of brown rice was increased from 2.2 to $2.36 \mathrm{gm} / \mathrm{gm}$. Cooking time was reduced from $29.1 \mathrm{~min}$ to $21.1 \mathrm{~min}$ with respect to power and time by cold plasma treatment (21). Plasma treatment at 120W-20s enhanced the cooking characteristics of milled rice by inducing to shorter cooking time, rough kernel surface, higher water absorption index, weak protein network and a higher speed of starch gelatinization (22). 
Amylose content play an important role influencing to the overall acceptabilities of cooking, eating and pasting attributes of a rice species $(27,28)$. The more amylose content a shorter cooking time was needed and vice versa. Amylose content in rice from 20 to $25 \%$ was greatly preferred as moist in cooking and soft even cooling (29). High amylose content in rice resulted dry and fluffy on boiling, but hard on cooling due to the retrogradation of amylose elements (27). Amylose content was strictly correlated to elongation of rice (30). Amylose content greatly influenced to the gelatinization, pasting behavior, swelling power, crystallinity and starch digestibility $(31,32)$. Water absorption index was an important variable in cooking rice. Water absorption index reflected the capability of grain to absorb and hold moisture against gravity. Acceleration of water absorption index after plasma treatment could be explained by the hydrolytic depolymerisation of starch (33). Water absorption index was greatly correlated to bulk density. The higher bulk density the higher water absorption index was achieved. Disorganized cellular structure induced the more probability for water absorption in cooking. Increase of water absorption index was strongly correlated to the decrease of the pasting temperature. The pasting temperature lowered as a result of increasing treatment duration. Plasma treatment etched the outer layer of polymeric membranes inducing to accumulation in hydrophilicity (34). Water solubility index illustrated the capability of particles to dissolve with water under an excess water condition. The water absorption index and swelling power reflected the interactions between the water molecules andthe starch chains in the crystalline and amorphous parts (25). The absorption index and swelling power proved a negative correlation with the amylose content (35). Rice consisted low amylose content had low pasting temperature (36). Rice grain had low pasting temperature resulted to shorter time of cooking as well as low energy consumption.

\section{Conclusion}

The present study revealed that technical variables of plasma treatment had significant impact to the physicochemical and functional attributes of ST25 fragrant rice flour, particularly degradation of amylose content and pasting temperature but improvement of water absorption index, water solubility index, swelling power. Plasma technology is effective to enhance quality characteristics of ST25 rice grain. The treated rice grain would become alternative raw material as gluten free ingredient for further processing different kinds of food with low glycemic index.

\section{Acknowledgements}

We acknowledge the financial support for the publication provided by Thu Dau Mot University, Binh Duong province, Vietnam.

\section{Authors' contributions}

Nguyen Phuoc Minh arranged the experiments and also wrote the manuscript.

\section{Conflict of interests}

The author strongly confirms that this research was conducted with no conflict of interest.

\section{References}

1. Cheng A, Mayes S, Dalle G, Demissew S, Massawe F. Diversifying crops for food and nutrition security-a case of teff. Biological Reviews. 2017;92:188-98. https://doi.org/10.1111/brv.12225

2. Swinnen J, Burkitbayeva S, Schierhorn F, Prishchepov AV, Muller D. Production potential in the "bread baskets" of Eastern Europe and Central Asia. Global Food Security. 2017;14:38-53. https://doi.org/10.1016/j.gfs.2017.03.005

3. Bhattacharya S, Tyagi S, Srisuma S, DeMeo DL, Shapiro SD, Bueno R, Silverman EK, Reilly JJ, Mariani TJ. Peripheral blood gene expression profiles in COPD subjects. Journal of Clinical Bioinformatics. 2011;1:12. https://doi.org/10.1186/2043-9113-112

4. Le TG, Pham QT, Dao HY. Identification of rice varieties specialties in Vietnam using Raman spectroscopy. Vietnam J Chem. 2020;58:711-18. https://doi.org/10.1002/vjch.202000017

5. Kostov $\mathrm{K}$, Rocha V, Koga-Ito C. Bacterial sterilization by a dielectric barrier discharge (dbd) in air. Surface and Coatings Technology.

https://doi.org/10.1016/j.surfcoat.2010.01.052

6. Khun J, Scholtz V, Hozak P, Fitl P, Julak J. Various dc- driven point-to-plain discharges as non-thermal plasma sources and their bactericidal effects. Plasma Sources Science and Technology. 2018;27,065002.

7. Sonal C, Chaitanya S, John J, Edwin C, Lucie C, Annaik G Brendan D, Paula B. Effect of atmospheric cold plasma on the functional properties of whole wheat (Triticum aestivum L.) grain and wheat flour. Innovative Food Science and Emerging Technologies.

https://doi.org/10.1016/j.ifset.2020.102529 2020;66:102529.

8. Metanee N, Srisuwan N, Phisit S, Yuthana P, Dheerawan B, Pilairuk I. Effects of plasma treatment on cooking and physical qualities of pigmented Thai rice. Chiang Mai University Journal of Natural Sciences. 2021;20,e2021004. https://doi.org/10.12982/CMUJNS.2021.004

9. Sarangapani C, Thirumdas R, Devi Y, Trimukhe A, Deshmukh RR, Annapure US. Effect of low-pressure plasma on physicochemical and functional properties of parboiled rice flour. LWT-Food Science and Technology. 2016;69:482-89. https://doi.org/10.1016/j.lwt.2016.02.003

10. Joye IJ, Lagrain B, Delcour JA. Use of chemical redox agents and exogenous enzymes to modify the protein network during breadmaking-a review. Journal of Cereal Science. 2009;50:1121. https://doi.org/10.1016/j.jcs.2009.04.001

11. Jiafeng J, Xin H, Ling L, Jiangang L, Hanliang S, Qilai X, Renhong Y, Yuanhua D. Effect of cold plasma treatment on seed germination and growth of wheat. Plasma Science and Technology. 2014;16:54. https://doi.org/10.1088/10090630/16/1/12

12. Dobrin D, Magureanu M, Mandache NB, Ionita MD. The effect of non-thermal plasma treatment on wheat germination and early growth. Innovative Food Science and Emerging Technologies https://doi.org/10.1016/j.ifset.2015.02.006 2015;29:255-60

13. Los A, Ziuzina D, Boehm D, Cullen PJ, Bourke P. Investigation of mechanisms involved in germination enhancement of wheat (Triticum aestivum) by cold plasma: Effects on seed surface chemistry and characteristics. Plasma Processes and 
Polymers.

https://doi.org/10.1002/ppap.201800148

$2019 ; 16,1800148$.

14. Scholtz V, Sera B, Khun J, Sery M, Julak J. Effects of nonthermal plasma on wheat grains and products. Journal of Food Quality. 2019;7917825,10. https://doi.org/10.1155/2019/7917825

15. Chen HH, Chang HC, Chen YK, Hung CL, Lin SY, Chen YS. An improved process for high nutrition of germinated brown rice production: Low-pressure plasma. Food Chem. 2016;191:120 27. https://doi.org/10.1016/j.foodchem.2015.01.083

16. Thirumdas R, Deshmukh RR, Annapure US. Effect of low temperature plasma processing on physicochemical properties and cooking quality of basmati rice. Innovative Food Science and Emerging Technologies. 2015;31:83-90. https://doi.org/10.1016/j.ifset.2015.08.003

17. Chen HH. Investigation of properties of long-grain brown rice treated by low-pressure plasma. Journal of Food Bioprocess Technology 2014;7:2484-91. https://doi.org/10.1007/s11947-013 $1217-2$

18. Sarangapani C, Devi Y, Thirundas R, Annapure US, Deshmukh RR. Effect of low-pressure plasma on physico-chemica properties of parboiled rice. Journal of Food Science and Technology. https://doi.org/10.1016/j.lwt.2016.02.003

2015;63:452-60.

19. Lee KH, Kim HJ, Woo KS, Kim SH, Park HY, Oh SK, Kim WH Evaluation of cold plasma treatments for improved microbial and physicochemical qualities of brown rice. LWT-Food $\begin{array}{lll}\text { Science and 2016;73:442-47. } & \text { Technology. }\end{array}$ https://doi.org/10.1016/j.lwt.2016.06.055

20. Sanjana P, Karunanithi S, Ravichandran S, Giridharan N, Radhakrishnan M. Effect of low-pressure plasma on bamboo rice and its flour. Journal of Food Processing and Preservation. 2018;42,e13846. https://doi.org/10.1111/jfpp.13846

21. Thirumdas R, Saragapani, C, Ajinkya MT, Deshmukh RR, Annapure US. Influence of low pressure cold plasma on cooking and textural properties of brown rice. Innovative. Food Science and Emerging Technologies 2016;37:53-60. https://doi.org/10.1016/j.ifset.2016.08.009

22. Jingjing L, Ruolan W, Zhitian C, Xingjun L. Effect of cold plasma treatment on cooking, thermomechanical and surface structural properties of chinese milled rice. Food and Bioprocess Technology. 2021;14:866-86. https://doi.org/10.1007/ s11947-021-02614-1

23. Thiranusornkij L, Thamnarathip P, Chandrachai A, Kuakpetoon D, Adisakwattana S. Comparative studies on physicochemical properties, starch hydrolysis, predicted glycemic index of Hom Mali rice and Riceberry rice flour and their applications in bread. Food Chem. 2019;283:224-31. https://doi.org/10.1016/j.foodchem.2019.01.048

24. De la hera E, Gomez M, Rosell CM. Particle size distribution of rice flour affecting the starch enzymatic hydrolysis and hydration properties. Carbohydr Polym. 2013;98:421-27. https://doi.org/10.1016/j.carbpol.2013.06.002

25. Phim S, Charoonsri C, Sirichai A. Physicochemical and functional characteristics of RD43 rice flour and its food application. Foods. https://doi.org/10.3390/foods9121912

26. Mohd FIM, Norizah R, Muhamad NFZ, Raja KRI, Norhayat A, Linda A. Emerging cold plasma treatment on rice grains: A $\begin{array}{lll}\text { mini } & \text { review. Chemosphere. 2021;274,129972. }\end{array}$ https://doi.org/10.1016/j.chemosphere.2021.129972
27. Adu-Kwarteng E, Ellis WO, Oduro I, Manful JT. Rice grain quality: A comparison of local varieties with new varieties under study in Ghana. Food Control 2003;14:507-14. https://doi.org/10.1016/S0956-7135(03)00063-X

28. Asghar S, Anjum FM, Amir MR, Khan MA. Cooking and eating characteristics of rice (Oryza sativa L.) -A review. Pakistan Journal of Food Sciences. 2012;22:128-32.

29. Rachel T, Wan-Nadiah WA, Rajeev B. Physiochemica properties, proximate composition, and cooking qualities of locally grown and imported rice varieties marketed in Penang, Malaysia. International Food Research Journal. 2013;20:1345 51. http://www.ifrj.upm.edu.my/20\%20(03)\%202013/45\%20IFRJ \%2020\%20(03)\%202013\%20Rajeev\%20(303).pdf

30. Nayak AR, Chaudhury D, Reddy JN. Interrelationship among quality characters in scented rice. Indian Journal of Agricultural Research. 2003;37:124-27.

31. Cai J, Man J, Huang J, Liu Q, Wei W, Wei C. Relationship between structure and functional properties of normal rice starches with different amylose contents. Carbohydr Polym. 2015;125:35-44. https://doi.org/10.1016/j.carbpol.2015.02.067

32. Chung HJ, Liu Q, Lee L, Wei D. Relationship between the structure, physicochemical properties and in vitro digestibility of rice starches with different amylose contents. Food Hydrocoll.

https://doi.org/10.1016/j.foodhyd.2010.09.011

33. Caballero B, Trugo L, Finglas P. Encyclopedia of food sciences and nutrition. Encyclopedia of Food Sciences and Nutrition. 2003; $2^{\text {nd }}$ edition: $1-10$.

34. Pankaj SK, Bueno-Ferrer C, Misra N, Milosavljevic V, O’donnell C, Bourke P, Cullen P. Applications of cold plasma technology in food packaging. Trends in Food Science and Technology. 2014;35:5-17. https://doi.org/10.1016/j.tifs.2013.10.009

35. Nakorn KN, Tongdang T, Sirivongpaisal P. Crystallinity and rheological properties of pregelatinized rice starches differing in amylose content. Starch Stärke. 2009;61:101-08. https://doi.org/10.1002/star.200800008

36. Ye L, Wang C, Wang S, Zhou S, Liu X. Thermal and rheological properties of brown flour from Indica rice. J Cereal Sci. 2016;70:270-74. https://doi.org/10.1016/j.jcs.2016.07.007

\section{Additional information}

Peer review information: Plant Science Today thanks Sectional Editor and the other anonymous reviewers for their contribution to the peer review of this work.

Reprints and permissions information is available at

https://horizonepublishing.com/journals/index.php/PST/open_access_policy

Publisher's Note: Horizon e-Publishing Group remains neutral with regard to jurisdictional claims in published maps and institutional affiliations.

To cite this article: Minh N P. Effectiveness of atmospheric cold plasma technology on physicochemical and functional characteristics of ST25 fragrant rice (Oryza sativa L.) flour. Plant Science Today. 2021;8(3):688-692.

https://doi.org/10.14719/pst.2021.8.3.1291

Plant Science Today, published by Horizon e-Publishing Group, is covered by Scopus, Web of Science, BIOSIS Previews, Clarivate Analytics, etc. See https://horizonepublishing.com/journals/index.php/PST/indexing_abstracting 